\title{
Paddy cum Fish Farming: A Case Study in Assam
}

\author{
R. Pegu ${ }^{1}$, Y.J. Singh ${ }^{1}$, P. Pal ${ }^{1}$, A.D. Upadhyay ${ }^{1}$, A. Sarkar ${ }^{1}$, \\ O.N. Khuman ${ }^{1}$ and H. Bharati ${ }^{2}$ \\ ${ }^{1}$ Department of Extension \& Social Sciences), College of Fisheries, CAU (I), \\ Tripura-799210, India \\ ${ }^{2}$ ICAR-RC for NEH Region, Tripura Centre, Lembucherra- 799210, India \\ *Corresponding author
}

\section{A B S T R A C T}

\section{Ke yw ords \\ Socio-economic, Socio-personal, Perception, Fish species diversity, Conservation, Paddy cum fish farmers, Assam \\ Article Info \\ Accepted: \\ 04 March 2019 \\ Available Online: \\ 10 April 2019}

The present study was conducted in Jorhat district of Assam, India to study the socioeconomic and socio-personal characteristics of the paddy cum fish farmers and their perception on fish species diversity and its conservation in the district. Eighty respondents were selected through snow ball sampling technique and data were collected using structured interview schedule. The study revealed that the majority $(63.75 \%)$ of the respondents belonged to young age out of which 92.50 per cent were male. Majority $(62.60 \%)$ of the respondents had medium ( 0.40 ha to 0.88 ha) level of area under paddy cum fish culture and majority $(70.00 \%)$ of respondents had medium level (Rs. 11054.08 to Rs. 24703.42) of annual income from paddy cum fish culture. The study also revealed that majority of the respondents $(57.50 \%)$ perceived that the fish catch has decreased as compared to the catch 5-10 years before whereas only 18.75 per cent of them felt that there is no change in fish catch. Majority $(52.50 \%)$ of the respondents had negative perception on the statement that fishing should be practiced when fish attain marketable size.

\section{Introduction}

Assam is one of the NE states of India wherein paddy cultivation is much prevalent and it serves as the staple food for the people in the state and forms as an essential part in their lives and culture. The paddy-cum-fish culture is an innovative farming system in which paddy is the main enterprise and fish fingerlings are taken as additional means to earn extra income.
In Assam, paddy cum fish culture is mostly practised in flooded river basins, unmanageable vast waterlogged area and perennial waterlogged wet rice lands, (highly prevalent in the districts of North Lakhimpur, Dhemaji, Kamrup, Barpeta, Nalbari, Dhuburi and Jorhat district of Assam) where fishes enter into the fields during monsoon and grow along with paddy. Fishing activities start after the recession of water during NovemberDecember and the fish farmers use various 
fishing gears like cast nets, gill nets, lift nets and also various traditional indigenous traps are either operated in the rice-free spots of the field or are fixed at appropriate water entry and exit points in the fields. In such system, the average capture rate is typically around 3 $\mathrm{kg} / \mathrm{ha} / \mathrm{yr}$ (Bhuyan, 2014). The state contributes 73 per cent to the whole regions in fish production and paddy-fish farming system contributes around 5.43 per cent in total production of fish in the state and around 2.3 million ha of seasonally flooded paddy land of Assam has the potentiality to fish production (Gogoi et al., 2015).

In Assam, fishes are introduced intentionally and are also found naturally in the paddy fields which got entered accidentally from the adjacent water bodies. Paddy species which grow in low lying areas or flood prone areas are broadly termed as "Baudhan" in Assam. Negeribau, Dolbau and Panijirika are some of the most popularly grown paddy species in the state. Paddy cum fish cultivation can make the farming practice more profitable since it is economically viable by providing more food and income to the people. Unfortunately, the per hectare paddy-cum-fish production is very low in the state due to the lack of proper scientific intervention in paddy-fish farming. Therefore, the present study was conducted in order to study the socio-economic and socio-personal characteristics of the paddy cum fish farmers and their perception on fish species diversity and its conservation.

\section{Materials and Methods}

The present study adopted 'DescriptiveDiagnostic' research design under cross sectional study in which ex-post approach was followed. For identification and selection of respondents, Department of Fisheries and Krishi Vigyan Kendra of the district were consulted. After purposive selection of Jorhat district, two blocks viz. Allengmara and Kaliyapani blocks were purposively selected. Six villages were purposively selected based on the prevalence of rice-fish farming activities. Eighty respondents who were involved in paddy-fish farming were selected from the 6 villages through snow ball sampling method. Data were collected from the respondents through personal interview at their home/ farm. Necessary rapport was developed before collection of data to ensure that the information furnished were genuine, objective and unbiased. Assamese language was used for data collection. Analysis and interpretation of the data collected both from primary and secondary sources were done to draw logical conclusion by using standard statistical techniques like-Frequency and Percentage, Arithmetic Mean, Standard deviation, Ranking.

\section{Results and Discussion}

\section{Socio-economic and socio-personal characteristics of the respondents}

The study observed that 63.75 per cent of the respondents belonged to young age category followed by 30.00 per cent and 6.25 per cent of respondents who belonged to middle age and old age categories respectively. However, this is in contrast to the study conducted by Baruah et al., (2014) and revealed that majority of paddy cum fish farmers (74\%) belonged to the middle age group (29 to 58 years). It was revealed that 92.50 per cent of the respondents were male and rest were female. A total of 45.00 per cent of the respondents studied upto high school level followed by 41.25 per cent, 12.50 per cent and 2.50 per cent who studied up to higher secondary level, middle school level and graduate respectively. Majority of the respondents $(52.50 \%)$ belonged to Other Backward Caste followed by Scheduled Tribe (35.00\%). Only 8.75 per cent and 3.75 per 
cent of respondents belonged to Scheduled Caste and General category respectively. Majority of the respondents $(83.75 \%)$ had experience up to 5 years in paddy cum fish farming followed by 12.50 per cent of the respondents who had experience between 6 to 10 years. Only 3.75 per cent of the respondents had experience on paddy cum fish farming between 11 to 15 years. None of the respondents had experience on paddy cum fish farming above 16 years. The study revealed that majority of the respondents $(53.75 \%)$ had not undergone any training on paddy cum fish farming. However, 46.25 per cent of the respondents had undergone training on paddy cum fish farming.

In terms of occupational multiplicity, majority (41.25\%) of the respondents had occupations comprising of paddy cum fish culture, crop, livestock, pond fish culture and wage earning. It was observed that almost all the households are marginal landholders. Majority (62.50\%) of the respondents had medium sized ( 0.40 ha to $0.88 \mathrm{ha}$ ) area under paddy cum fish farming followed by 20 per cent of the respondents who had small sized (less than 0.40 ha) area under paddy cum fish farming. Only 17.50 per cent of respondents had large sized (more than 0.88 ha) area under paddy cum fish farming.

A majority of the respondents $(72.50 \%)$ had medium level of annual household income followed by 13.75 per cent of the respondents who had high level of income and low level of income respectively.

It was observed that 70.00 per cent of the respondents had medium level of annual income (₹ 11054.08 to ₹ 24703.42) from paddy cum fish culture system followed by 16.25 per cent and 13.75 per cent of the respondents who had low level of income (less than ₹ 11054.08) and high level of income (above ₹ 24703.42) respectively.
Majority $(62.50 \%)$ of the respondents had medium sized ( 0.40 ha to $0.88 \mathrm{ha}$ ) area under paddy cum fish farming followed by 20 per cent of the respondents who had small sized (less than $0.40 \mathrm{ha}$ ) area under paddy cum fish farming. Only 17.50 per cent of respondents had large sized (more than $0.88 \mathrm{ha}$ ) area under paddy cum fish farming. In case of annual income from paddy cum fish culture system, the majority of the respondents belong to medium level of annual income that is 70.00 per cent of the total respondents.

Majority $(70.00 \%)$ of the respondents had medium level of extent to natural capital while 16.25 per cent of respondents and 13.75 had high and low level of extent to natural capital respectively. A total of 32.50 per cent and 27.50 per cent of the respondents were members of Self-Help Group and religious committee respectively. Around 25.00 per cent of the respondents were members of the rural youth club, 3.75 per cent of the respondents were members of the credit cooperative society, 2.50 per cent of them were members of political organisations, and 2.5 per cent of them were members of Gram Panchayat. None of the respondents were office bearers of the Gram Panchayat, Cooperative Society, Cooperative society, Rural Youth Club, Religious Committee, Political Organisation, Anganwari and Self Help Group.

It was found that majority of the respondents $(60.00 \%)$ were found to have medium level of innovativeness. While, only 23.75 per cent and 16.25 per cent of the respondents had high and low level of innovativeness respectively. Majority (66.25\%) of the respondents had medium level of economic motivation followed by 17.50 per cent and 16.25 per cent of respondents who had economic motivation level of high and low respectively. With regard to mass media exposure, it was observed that 90.00 per cent 
of the respondents use the assistance of Kisan call centres

It was revealed that 42.50 per cent of respondents consulted with Assistant Director of Agriculture occasionally and only 1.25 per cent of them consulted regularly. It was also found that 8.75 per cent of the respondents consulted with Assistant Horticulture Officers occasionally. It was observed that majority $(73.75 \%)$ had occasionally consulted the subject matter specialists of KVKs and 2.50 per cent of the respondents had consulted the subject matter specialists of KVKs regularly. A total of 33.75 per cent of the respondents consulted private extension consultant occasionally. Further, 21.25 per cent of the respondents consulted NGOs occasionally and 3.75 per cent consulted NGOs regularly. Majority $(70.00 \%)$ of the respondents occasionally consulted progressive farmers, 55.00 per cent of respondents occasionally consulted family and friends, 60.00 per cent of the respondents consulted their neighbours occasionally and 27.50 per cent consulted their neighbour regularly. Further, majority $(76.25 \%)$ of the respondents occasionally used mass media for seeking information on paddy cum fish farming.

\section{Perception of respondents on fish diversity}

The data in Table 1 showed that majority $(57.50 \%)$ of respondents had a perception that the fish catch is decreased as compared to the catch 5-10 years before even after using the same fishing effort. Only 18.75 per cent of the respondents felt that there is no change in fish catch. However, 2.50 per cent of the respondents felt that the fish catch is increased from before. Majority $(72.50 \%)$ of the respondents felt that there is decrease in the availability of fish species diversity while 17.50 per cent of them felt that there is no change in species diversity at all. Majority $(52.50 \%)$ of the respondents expressed that the average size of the fish has been decreased whereas 33.75 per cent of the respondents said that there was no change in average size of species as compared with before.

The study revealed that majority of the respondents $(57.50 \%)$ perceived that fishing is important for securing their livelihood followed by a small proportion (16.25\%) of respondents who perceived fishing as very important for their livelihood security. However, only 10 percent of respondents perceived fishing as unimportant for their livelihood security.

\section{Perception of respondents on conservation}

It was observed from Table 2 that majority $(52.50 \%)$ of the respondents had negative perception on the statement that fishing should be practiced when fish attain marketable size. Only 2.50 per cent of respondents perceived that fishing should be practised when fish attain marketable size. Majority $(42.50 \%)$ of the respondents perceived that the variety of paddy should be chosen according to water level in the paddy field. Majority (51.25\%) of respondents had a perception that the paddy cum fish farmers should apply different ITKs to protect their field from flood whereas 26.25 per cent of the respondents perceived the otherwise. A significant number of respondents $(60.00 \%)$ had a perception that the quality and quantity of paddy seed and fish seed need not be considered in paddy cum fish farming and only 30.00 per cent of them perceived that they have to be well considered in paddy cum fish farming. Highest portion $(73.75 \%)$ of the respondents perceived that selection of proper fishing method and appropriate mesh size should be considered for fishing in paddy cum fish culture system and only 6.25 per cent of them perceived the otherwise. 
Distribution of respondents according to fishing season, time, gear, fish species and paddy variety

According to majority $(76.25 \%)$ of the respondents, fishing is practised in both monsoon and post monsoon while only 23.75 per cent of respondents perceived that fishing is only practised in monsoon season. Majority $(63.75 \%)$ of the respondents revealed that fishing in generally done during day time while only 21.25 per cent of respondents perceived that it is done during night.

However, 15 per cent of the respondents mentioned that fishing is done both at day and night (Table 1). It was observed that 70 per cent of the paddy cum fish farmers used trap while 27.50 per cent of them used net as fishing gear for harvesting. A total of 72.50 percent of the farmers were found to use both net and trap for fishing (Table 3).

Table.1 Distribution of the respondents according to their perception on fish diversity

\begin{tabular}{|c|c|c|c|c|c|}
\hline $\begin{array}{l}\text { Sl. } \\
\text { No. }\end{array}$ & Perception & Increased & Decreased & Can't say & No change \\
\hline 1 & $\begin{array}{l}\text { Has your fish catch increased or decreased } \\
\text { using the same fishing effort as compared } \\
\text { to } 5-10 \text { years before? }\end{array}$ & $\begin{array}{c}2 \\
(2.50 \%)\end{array}$ & $\begin{array}{c}46 \\
(57.50 \%)\end{array}$ & $\begin{array}{c}17 \\
(21.25 \%)\end{array}$ & $\begin{array}{c}15 \\
(18.75 \%)\end{array}$ \\
\hline 2 & $\begin{array}{l}\text { Has the species diversity increased/ } \\
\text { decreased using the same fishing effort as } \\
\text { compared to 5-10 years before? }\end{array}$ & $\begin{array}{c}0 \\
(0.00 \%)\end{array}$ & $\begin{array}{c}58 \\
(72.50 \%)\end{array}$ & $\begin{array}{c}8 \\
(10.00 \%)\end{array}$ & $\begin{array}{c}14 \\
(17.50 \%)\end{array}$ \\
\hline \multirow[t]{2}{*}{3} & $\begin{array}{l}\text { Whether the average size of the different } \\
\text { fish species caught is changed as } \\
\text { compared to 5-10 years before? }\end{array}$ & $\begin{array}{c}2 \\
(2.50 \%)\end{array}$ & $\begin{array}{c}42 \\
(52.50 \%)\end{array}$ & $\begin{array}{c}9 \\
(11.25 \%)\end{array}$ & $\begin{array}{c}27 \\
(33.75 \%)\end{array}$ \\
\hline & Perception & $\begin{array}{c}\text { Very } \\
\text { important }\end{array}$ & Important & Undecided & $\begin{array}{c}\text { Not } \\
\text { important }\end{array}$ \\
\hline 4 & $\begin{array}{l}\text { Overall importance of fishing for securing } \\
\text { the livelihood? }\end{array}$ & $\begin{array}{c}13 \\
(16.25 \%)\end{array}$ & $\begin{array}{c}46 \\
(57.50 \%)\end{array}$ & $\begin{array}{c}13 \\
(16.25 \%)\end{array}$ & $\begin{array}{c}8 \\
(10.00 \%)\end{array}$ \\
\hline
\end{tabular}

Table.2 Distribution of the respondents according to their perception on conservation

\begin{tabular}{|c|c|c|c|c|}
\hline \multirow[b]{2}{*}{$\begin{array}{l}\text { Sl. } \\
\text { No. }\end{array}$} & \multirow[b]{2}{*}{ Perception } & & \multicolumn{2}{|c|}{$(\mathrm{n}=80)$} \\
\hline & & Agree & Disagree & Can't say \\
\hline 1 & $\begin{array}{l}\text { Fishing should be practiced when the fish attain } \\
\text { marketable size. }\end{array}$ & $\begin{array}{c}2 \\
(2.50 \%)\end{array}$ & $\begin{array}{c}42 \\
(52.50 \%)\end{array}$ & $\begin{array}{c}3 \\
(45.00 \%)\end{array}$ \\
\hline 2 & $\begin{array}{l}\text { Paddy variety should be chosen according to water } \\
\text { level }\end{array}$ & $\begin{array}{c}14 \\
(17.50 \%)\end{array}$ & $\begin{array}{c}34 \\
(42.50 \%)\end{array}$ & $\begin{array}{c}32 \\
(40.00 \%)\end{array}$ \\
\hline 3 & $\begin{array}{l}\text { Different ITKs should be applied to protect paddy field } \\
\text { from flood. }\end{array}$ & $\begin{array}{c}41 \\
(51.25 \%)\end{array}$ & $\begin{array}{c}21 \\
(26.25 \%)\end{array}$ & $\begin{array}{c}18 \\
(22.50 \%)\end{array}$ \\
\hline 4 & $\begin{array}{l}\text { The quantity of application of pesticide and fertilizer } \\
\text { should be reduced in paddy cum fish farming. }\end{array}$ & $\begin{array}{c}26 \\
(32.50 \%)\end{array}$ & $\begin{array}{c}19 \\
(23.75 \%)\end{array}$ & $\begin{array}{c}35 \\
(43.75 \%)\end{array}$ \\
\hline 5 & $\begin{array}{l}\text { The quality and quantity of paddy seed and fish seed } \\
\text { should be considered before stocking the fish }\end{array}$ & $\begin{array}{c}24 \\
(30.00 \%)\end{array}$ & $\begin{array}{c}48 \\
(60.00 \%)\end{array}$ & $\begin{array}{c}8 \\
(10.00 \%)\end{array}$ \\
\hline 6 & $\begin{array}{l}\text { Selection of proper fishing method and appropriate } \\
\text { mesh size should be considered for fishing. }\end{array}$ & $\begin{array}{c}5 \\
(6.25 \%)\end{array}$ & $\begin{array}{c}59 \\
(73.75 \%)\end{array}$ & $\begin{array}{c}16 \\
(20.00 \%)\end{array}$ \\
\hline
\end{tabular}


Table.3 Distribution of respondents $(n=80)$ according to fishing season, fishing time and gear

\begin{tabular}{|c|c|c|c|c|}
\hline Sl. No. & Category & \multicolumn{3}{|c|}{ Frequency (percentage) } \\
\hline 1 & Fishing & Monsoon & Post monsoon & Both \\
\cline { 3 - 5 } & season & $19(23.75 \%)$ & $0(0.00)$ & $61(76.25 \%)$ \\
\hline 2 & Fishing time & Day & Night & Both \\
\cline { 3 - 5 } & & $51(63.75 \%)$ & $17(21.25 \%)$ & $12(15.00 \%)$ \\
\hline 3 & \multirow{2}{*}{ Fishing gear } & Trap & Net & Trap and net \\
\cline { 3 - 5 } & & $56(70.00 \%)$ & $22(27.50 \%)$ & $58(72.50 \%)$ \\
\hline
\end{tabular}

Table.4 List of naturally found fish species in paddy cum fish farming systems $(\mathrm{n}=80)$

\begin{tabular}{|c|c|c|}
\hline SI. No. & Fish species found in paddy field. & No of responses \\
\hline 1 & Clarias $\mathrm{spp}$ & $47(58.75 \%)$ \\
\hline 2 & Channa $\mathrm{spp}$ & $77(96.25 \%)$ \\
\hline 3 & Puntius $\mathrm{spp}$ & $78(97.50 \%)$ \\
\hline 4 & Badis $\mathrm{spp}$ & $51(63.75 \%)$ \\
\hline 5 & Botia $\mathrm{spp}$ & $27(33.75 \%)$ \\
\hline 6 & Mastcembeluas $\mathrm{spp}$ & $53(66.25 \%)$ \\
\hline 7 & Nototopteras $\mathrm{spp}$ & $11(13.75 \%)$ \\
\hline 8 & Glossogobius $\mathrm{spp}$ & $66(82.50 \%)$ \\
\hline 9 & Colisa spp & $66(82.50 \%)$ \\
\hline 10 & Mystus spp & $49(61.25 \%)$ \\
\hline 11 & Amlypharingodon mola & $76(95.00 \%)$ \\
\hline 12 & Anabus testudinus & $41(51.25 \%)$ \\
\hline 13 & Walagu attu & $12(15.00 \%)$ \\
\hline 14 & Xenontododon cancila & $26(32.50 \%)$ \\
\hline
\end{tabular}

Table.5 Rice and fish yield from paddy cum fish farming system $(\mathrm{n}=80)$

\begin{tabular}{|c|c|c|c|}
\hline Sl. No. & Range of rice yield $(\mathrm{kg} / \mathrm{ha})$ & No of responses & Rank \\
\hline 1 & $<1500$ & $4(5 \%)$ & III \\
\hline 2 & $>1500-2000$ & $58(72.50 \%)$ & I \\
\hline 3 & $>2000-2500$ & $15(18.75 \%)$ & II \\
\hline 4 & $>2501$ & $3(3.75 \%)$ & IV \\
\hline & Range of fish yield $(\mathrm{kg} / \mathrm{ha}$.) & No of responses & Rank \\
\hline 1 & $<300$ & $46(57.50 \%)$ & I \\
\hline 2 & $>301-450$ & $20(25.00 \%)$ & II \\
\hline 3 & $>451-600$ & $12(15.00 \%)$ & III \\
\hline 4 & $>601$ & $2(2.50 \%)$ & IV \\
\hline
\end{tabular}

The fish species available in the paddy cum fish farming system is enlisted in Table 4 based on the responses from the farmers. The majority of the respondents revealed that Puntius spp dominated the paddy fish farming system followed by Channa spp (96.25\%), 
Amlypharyngodon mola (95.00\%), Glossogobius sp. (82.50\%), Colisa spp (82.50\%), Mastacembelus spp (66.25\%), Badis sp. (63.75\%), Mystus spp (61.25\%), Clarias magur (58.75\%), Anabus testudinus (51.25\%), Botia spp (33.75\%), Xenontododon cancila $(32.50 \%)$, Walagu attu (15.00\%) and Nototopteras $\operatorname{spp}(13.75 \%)$.

\section{Rice and fish yield from paddy cum fish} farming system of Assam

Table 3 describes the yield obtained from paddy cum fish farming systems of Assam. The observed rice varieties cultivated under paddy cum fish farming systems were Dolbau, Negeribau, Panijirika, Jalpriya and Swarna. The average rice yield of the respondents was found to be $1896.25 \mathrm{~kg} / \mathrm{ha}$ from paddy cum fish culture. Majority of the respondents $(72.50 \%)$ achieved yield between $1500-2000 \mathrm{~kg} / \mathrm{ha}, 18.75$ per cent achieved yield between $2000-2500 \mathrm{~kg} / \mathrm{ha}, 5.00$ per cent achieved yield upto $1500 \mathrm{~kg} / \mathrm{ha}$ and 3.75 per cent of respondents achieved yields higher than $2500 \mathrm{~kg} / \mathrm{ha}$.

The average fish yield from paddy cum fish culture was found to be $344.38 \mathrm{~kg} / \mathrm{ha}$. Majority of the respondents $(57.50 \%)$ attained fish yield below $300 \mathrm{~kg} / \mathrm{ha}, 25.00$ per cent of the respondents attained fish yield between $301-450 \mathrm{~kg} / \mathrm{ha}, 15.00$ per cent attained fish yield between $451-600 \mathrm{~kg} / \mathrm{ha}$ and only 2.50 per cent of respondents attained fish yield higher than $601 \mathrm{~kg} / \mathrm{ha}$ (Table 3).

Based on the findings of this study and personal observation of researcher at the time of data collection and interaction with the respondents, following recommendation are made (Table 5).

Most of the respondents belonged to young age category who have less experience in paddy fish farming and therefore awareness programme and support from Department of Fisheries, KVK and other relevant organisation is essential to support and to motivate these youths.

There is a need for application of scientific method in paddy-cum-fish farming. Therefore, specific and need based training and demonstration programmes should be conducted

Majority of the respondents had low social participation which means that proper coordination and linkage among different organization and stakeholders need to be strengthened and they should work collaboratively to motivate the farmers for more participation in paddy cum fish farming.

Very few number of farmers practise paddy cum fish farming wherein they stock fingerlings, provide supplementary feed and manage the system for better production. This practice should be encouraged more and strong market network should be established for better inputs (seed, feed) supply and outputs (rice, fish) supply.

\section{Acknowledgement}

The authors thankfully acknowledged the support and facilities provided by Dean, College of Fisheries, Lembucherra, CAU(I), Tripura.

\section{References}

Bhuyan, D. 2014. Paddy cum fish farming - a sustainable way of agriculture, practiced in Jorhat district of Assam, with special reference to Hatigarh village. Journal of aquatic biology and fisheries. 2: 126132.

Gogoi, B., Kachari, A., Dutta, R., Darshan, A. and Das, D.N. 2015. Fishery based livelihood approaches and management 
of fishery resources in Assam, India. International journal of fisheries and aquatic studies. 2(4): 327-330.

Baruah, U.K., Mazumdar, M. and Rabha, H.P. 2014. Rice field sumps: indigenous technology for catching fish in rice field. Scholars Journal of Agriculture and Veterinary Sciences. 1(3): 149-152.

\section{How to cite this article:}

Pegu, R., Y.J. Singh, P. Pal, A.D. Upadhyay, A. Sarkar, O.N. Khuman and Bharati, H. 2019. Paddy cum Fish Farming: A Case Study in Assam. Int.J.Curr.Microbiol.App.Sci. 8(04): 373380. doi: https://doi.org/10.20546/ijcmas.2019.804.041 